\title{
New Records of Cladocera (Crustacea: Anomopoda) from Laguna Navío Quebrado, La Guajira Department, Colombia
}

\author{
Juan Manuel Fuentes-Reinés
}

Grupo de investigación en Limnología Neotropical, Universidad del Magdalena. A.A 731 Santa Marta, Magdalena, Colombia. E-mail: juanmanuelfuentesreines@yahoo.com

\begin{abstract}
Zooplankton plays key roles in structuring interactions in aquatic communities but often remain undescribed in many water systems. This paper reports seventeen species of the Cladocera (Crustacea: Branchiopoda) from Laguna de Navío Quebrado, all of them new records for La Guajira Department, Colombia. The Cladocera assemblages include mostly the Neotropical taxa associated with vegetation. This paper also serves as the first compilation of the data on the Cladocera of this region and includes brief remarks, descriptions and illustrations of some species with additional notes on their distribution.
\end{abstract}

Key words: Cladocera, Colombia, distribution, Neotropics, species composition, taxonomy.

\section{INTRODUCTION}

Cladocerans are aquatic branchiopod microcrustaceans that show a considerable range in size $(0.2-6 \mathrm{~mm}$, and even $1.8 \mathrm{~cm}$ in case of the genus Leptododa Lilljeborg, 1861). They inhabit pelagic, littoral and benthic zone, and most of them prefer freshwater bodies. At present, 620 species of Cladocera are recognized as valid in the world fauna (Forró et al., 2008). They belong to four orders: Anomopoda, Ctenopoda, Onychopoda, and Haplopoda (Frey, 1987).

In the Americas, México, Belize, Guatemala, Cuba, Venezuela, Brazil, and Argentina represent the countries with most studied cladoceran fauna (Elmoor-Loureriro, 1997; Paggi, 2004; Elias-Gutiérrez et al., 2006; Zoppy and López, 2008; Elias-Gutiérrez et al., 2008; Elias-Gutiérrez and Varela, 2009). In Colombia, the knowledge about freshwater cladocerans still remains inadequate, although a few old publications are well-known: Stingelin (1913) reported 23 species from Colombia Mountains; Pearse (1915) recorded five species in the material collected by the Walker Expedition to Santa Marta and Brehm (1956) found nine species in Barranquilla Department.
The interest to the cladoceran studies in Colombia is increased during last decade. Barón-Rodríguez and Díaz (2007) reported on the occurrence of Ephemeroporus tridentatus Bergamin, 1939 in Ciénaga de Paredes (Sántander). Aranguren-Riaño et al. (2010) described a new species of Cladocera, Eurycercus norandinus Aranguren, Monroy \& Gaviria, 2010 from Lago de Tota (Sántander). The same taxon was described one month later by Bekker et al. (2010) from Lake Regadera as E. dumonti (Bekker, Kotov \& ElmoorLoureiro, 2010), and could be regarded as a junior synonym of the former. The Ciénaga Grande de Santa Marta, located in Magdalena Department is now the water system with the most studied Cladocera fauna in Colombia (Fuentes-Reinés and Elmoor-Loureiro, 2011; Fuentes-Reinés et al., 2012; Fuentes-Reinés and Zoppi de Roa, 2013).

Other territories from Colombia still poorly studied. Up to now, no single adequate study of the Cladocera of La Guajira Department (the northernmost extremity of Colombia) has been compiled. This study is aimed to investigate the cladoceran fauna of Laguna Navío Quebrado, provide descriptions 
and appropriate illustrations of some remarkable taxa, and improve our knowledge on the distribution of some cladoceran species in Colombia.

\section{Material And Methods}

I studied 108 samples collected of the North coast of Laguna Navío Quebrado, adjacent to Camarón river, Guajira Department (110 $25^{\prime} \mathrm{N}$ and $\left.73^{\circ} 5^{\prime} \mathrm{W}\right)$. The samples were taken monthly, from April to December 2012, in the littoral zone (covered by macrophytes) and pelagic zones in regions of oyster banks. Water salinity ranged from 0 to 28 PSU. Water samples were collected using a bucket of $25 \mathrm{~L}$ in both vegetation areas and open water, then filtered through a plankton net $(45 \mu \mathrm{m})$, and the filtered contents preserved in $70 \%$ ethanol. Samples were sorted under a dissective stereomicroscope Urano 40X. Specimens were placed to glycerol drops on slides, studied in toto and then some of them were dissected for study of fine morphological details. Dissected specimens and appendages were mounted in glycerine and sealed with Canada balsam. The mounted specimens and their body parts were photographed using a Kodak Easy Share C140 digital camera adapted to a compound microscope Olympus CX22.

The specimens were measured in lateral position, from head to the posterior part of the valve. Identifications were made according to the papers of Elmoor-Loureiro (1997), Sinev (2001), Sinev and Hollwedel (2002), Van Damme et al. (2011) and Elías-Gutiérrez et al. (2008).

Specimens were deposited at the Museo de Colecciones Biológicas de la Universidad del Atlántico - Colombia (UARC). The following abbreviation are used in the text: IDL (inner distal lobe of limb I), ODL (outer distal lobe of limb I); PP (postpore distance), IP (interpore distance).

\section{Results}

Seventeen species reported here include new records for La Guajira department. They belong to five families and 14 genera (Tab. 1). The family Chydoridae exhibited the highest species richness (12), followed by Macrothricidae (2), Daphnidae, Moinidae, Ilyocryptidae (a single species in each).

Table 1. Species of Cladocera from Laguna Navío Quebrado and its distribution. Geographic category: NT (Neotropical), C (Cosmopolita), NA (Nearctic) and TR (Tropicopólita). Departments: At (Atlántico), An (Antioquia), Co (Córdoba), Ch (Chocó), $\mathrm{Cu}$ (Cundinamarca), H (Huila), Sa (Santander), S (Sucre), Mg (Magdalena).

\begin{tabular}{|c|c|c|c|c|c|}
\hline Order & Family & Species & \begin{tabular}{|l|}
$\begin{array}{l}\text { Distribution in } \\
\text { Colombia }\end{array}$ \\
\end{tabular} & \begin{tabular}{|l|}
$\begin{array}{l}\text { World } \\
\text { distribution }\end{array}$ \\
\end{tabular} & References to Colombia \\
\hline & Daphnidae & Ceriodaphnia cornuta Sars, 1885 & $\begin{array}{l}\text { At, } \mathrm{H}, \mathrm{Co}, \mathrm{Ch}, \\
\text { Sa }, \mathrm{Mg}\end{array}$ & C & $\begin{array}{l}\text { Camargo, 1994; Herrera and Guillot, 1999; } \\
\text { Barón-Rodríguez et al., 2006; Álvarez, 2010; } \\
\text { Fuentes et al., } 2012\end{array}$ \\
\hline & Moinidae & Moinodaphnia macleayi (King, 1853) & $\mathrm{Sa}, \mathrm{Co}, \mathrm{Mg}$ & C & $\begin{array}{l}\text { Pearse, 1915; Barón-Rodríguez et al., 2006; } \\
\text { Álvarez, 2010; Fuentes-Reinés et al., } 2012\end{array}$ \\
\hline & Ilyocryptidae & Ilyocryptus spinifer Herrick, 1882 & An, Cu Sa, Mg & $\mathrm{C}$ & $\begin{array}{l}\text { Gaviria, 2001; Barón-Rodríguez et al., 2006; } \\
\text { Fuentes-Reinés et al., } 2012\end{array}$ \\
\hline & Macrothricidae & Macrothrix elegans Sars, 1901 & $\mathrm{Co}, \mathrm{Mg}$ & NT & Álvarez, 2010; Fuentes et al., 2012 \\
\hline & & Macrothirx spinosa (King, 1853) & $\mathrm{Co}, \mathrm{Mg}$ & C & Álvarez, 2010; Fuentes-Reinés et al. 2012 \\
\hline & & & Aloninae & & \\
\hline \multirow{13}{*}{ Anomopoda } & & Alona glabra Sars, 1901 & $\mathrm{Mg}, \mathrm{Cu}$ & NT & Stingelin, 1913; Fuentes-Reinés et al., 2012 \\
\hline & & Karualona muelleri (Richard, 1897) & $\mathrm{Mg}$, Co & NT & $\begin{array}{l}\text { Pearse, 1915; Álvarez; 2010, Fuentes-Reinés et } \\
\text { al. } 2012\end{array}$ \\
\hline & & Oxyurella ciliata (Bergamin, 1939) & $\mathrm{Co}, \mathrm{Mg}$ & NT & Álvarez, 2010; Fuentes-Reinés et al., 2012 \\
\hline & & Leberis davidi (Richard, 1895) & $\mathrm{Co}, \mathrm{Mg}$ & NT & Álvarez, 2010; Fuentes-Reinés et al., 2012 \\
\hline & & Euryalona orientalis (Daday, 1898) & $\mathrm{Mg}$ & TR & Pearse, 1915; Fuentes-Reinés et al., 2012 \\
\hline & & Nicsmirnovius fitzpatricki (Chien, 1970) & $\mathrm{Mg}$ & NT & Fuentes-Reinés and Zoppy, 2013 \\
\hline & Chydoridae & Anthalona verrucosa (Sars, 1901) & $\mathrm{Co}, \mathrm{Mg}$ & NT & Álvarez, 2010; Fuentes-Reinés et al., 2012 \\
\hline & & Notoalona sculpta (Sars, 1901 & At, $\mathrm{Mg}$ & NT & Brehm, 1956; Fuentes-Reinés et al., 2012 \\
\hline & & & Chydorinae & & \\
\hline & & Chydorus nitidulus (Sars, 1901) & At, Co, Mg & NT & $\begin{array}{l}\text { Stingelin, 1913; Álvarez, 2010; Fuentes-Reinés } \\
\text { et al., } 2012\end{array}$ \\
\hline & & Chydorus eurynotus (Sars, 1901) & $\mathrm{Co}, \mathrm{Mg}$ & TR & Álvarez, 2010; Fuentes-Reinés et al., 2012 \\
\hline & & Chydorus pubescens (Sars, 1901) & $\mathrm{Co}, \mathrm{Mg}$ & TR & Álvarez, 2010; Fuentes-Reinés et al., 2012 \\
\hline & & Dunhevedia odontoplax Sars, 1901 & $\mathrm{Cu}, \mathrm{Mg}$ & NT & Stingelin, 1913; Fuentes-Reinés et al., 2012 \\
\hline
\end{tabular}


Within the family Chydoridae, only the genus Chydorus Leach, 1816 was represented by three species, followed by Macrothrix Baird, 1843 (2 species). Each of the remaining genera was represented by a single species. A brief remarks, descriptions and illustrations about the more frequent and abundant species are given below.

Family Daphniidae Straus, 1820

Genus Ceriodaphnia Dana, 1853

Ceriodaphnia cornuta Sars, 1885

Syn: Fuentes-Reinés et al., 2012:128, fig. 7; FADA 2013:14.

Material examined: 5 adult females, catalog number: UARC124M.

Remarks: It was found within the macrophytes during April-May. This species was formally described from Australia (Sars, 1885) and then found everywhere in tropics. But in reality this is a large group of taxa, specific in different continents (Elias-Gutiérrez et al., 2008; Sharma and Kotov, 2013). It is a polymorphic species (Zaret, 1969), and very common in freshwaters of tropics and subtropics (Villalobo and González, 2006).

Genus Moinodaphnia Herrick, 1887

Moinodaphnia macleayi (King, 1853)

Syn: Goulden, 1968:84, fig. 46. Fuentes-Reinés et al., 2012: 136, fig. 15; FADA 2013:42.

Material examined: 10 adult females, catalog number: UARC128M.

Remarks: This species was found within macrophytes in September. It is a mesobenthic species that inhabit small lakes, swamp and pools (Goulden, 1968). The genus is regarded as monotypical, and needs to be revised worldwide (Smirnov, 1976).

Family Ilyocryptidae Smirnov, 1976 sensu Smirnov, 1992

Genus Ilyocryptus Sars, 1862

Ilyocryptus spinifer Herrick, 1882

Syn: Kotov and Stifter, 2006:139, figs. 69-70; Fuentes-Reinés et al., 2012:134, fig 13.

Material examined: 8 adult females, catalog number: UARC115M.

Remarks: This species was described from USA (Herrick, 1882). It is a benthic organism (Sousa and Elmoor-Loureiro, 2008) and was found within macrophytes in April, September and October. Among Ilyocryptidae, $I$. spinifer is the most frequently reported from Colombia (Stingelin, 1913; Gaviria, 2001; Barón-Rodríguez et al., 2006). This species is considered dominant among ilyocriptids from the subtropical and tropical waters (Kotov and Dumont, 2000).

Family Macrothricidae Norman et Brady, 1867 Genus Macrothrix Baird, 1843

Macrothrix elegans Sars, 1901

Syn: Kotov et al., 2004:62, figs. 1-123.

Material examined: 4 adult females, catalog number: UARC125M.

Remarks: It was found among the macrophytes in June. This is the most common Neotropical species of Macrothrix (Kotov et al., 2004). Earlier it was considered a junior synonym of Macrothrix triseralis Brady 1886 (Smirnov, 1976). Nevertheless, Dumont et al., 2002 demonstrated that it is a valid species. Macrothrix elegans Sars, 1901 was confused with $M$. superaculeata, however, separation of the two latter species was confirmed by Kotov et al. (2004).

Macrothrix spinosa (King, 1853)

Syn: Smirnov, 1992: 29, figs. 60-93. FuentesReinés et al., 2012:130, fig. 10.

Material examined: 2 adult females, catalog number: UARC129M.

Remarks: This species was the least abundant within the Macrothrix genus and was found in October. It is valid species described from Australia (King, 1853), very common in tropics (Smirnov, 1976) and needs to be revised worldwide.

Family Chydoridae Dybowski et Grochowski, 1894 emend. Frey 1967

Genus Karualona Dumont et Silva-Briano, 2000

Karualona muelleri (Richard, 1897) 
Syn: Fuentes-Reinés et al., 2012:149, fig. 28; Van Damme and Dumont, 2010: 767, fig. 7.

Material examined: 10 adult female, catalog number: UARC118M.

Remarks: This species was common within macrophytes from April to May. It was initially described as Alona mülleri Richard, 1897 from Lunache, Chile (Richard, 1897) and allocated to genus Karualona Dumont and Silva-Briano, 2000 by Sinev and Hollwedel (2005). The first report of this species for Colombia was as Allonella karua by Pearse (1915). It is a common Neotropical taxon.

Genus Oxyurella Dybowski et Grochowski, 1894

Oxyurella ciliata Bergamin, 1939

Syn: Smirnov (1974):605.

Material examined: 3 adult females, catalog number: UARC119M.

Remarks: It was one of the species less abundant and collected only in October. It is a valid species (Smirnov, 1971) described from Brazil (Bergamin, 1939).

Genus Leberis Smirnov, 1989

Leberis davidi (Richard, 1895)

Syn: Sinev et al., 2005:193, figs. 60-150. Fuentes-Reinés et al., 2012:149, fig. 29.

Material examined: 15 adult females, catalog number: UARC120M.

Remarks: It was a common species in many samples, collected in April, May, June, July and November. The species was described from Haiti as Alona davidi by Richard (1895) and then transferred to the genus Leberis (Sinev et al., 2005). It is a Neotropical taxon (Kotov and Ferrari, 2010).

Genus Euryalona Sars, 1901

Euryalona orientalis (Daday, 1898)

Syn: Fuentes-Reinés et al., 2012:146, fig. 25.

Material examined: 5 adult females, catalog number: UARC116M.
Remarks: It was found within macrophytes in December and reported for the first time in Colombia as Euryalona occidentalis by Pearse (1915). This species is very common in the subtropics and tropics. E. orientalis could be a species complex and needs to be revised worldwide (Kotov et al., 2013; Van Damme and Maiphae, 2013).

Genus Notoalona Rajapaksa et Fernando, 1987 Notoalona sculpta (Sars, 1901)

Syn: Fuentes-Reinés et al., 2012:146, fig. 26.

Material examined: 15 adult females, catalog number: UARC126M.

Remarks: It was rare within macrophyte and found only in July. N. sculpta was described from Brazil (Sars, 1901) as Alonella and then translocated to Notoalona (Rajapaksa and Fernando, 1987). This is a Neotropical species, which needs to be re-studied again after a significant increasing of level of morphological analysis during last two decades.

Genus Chydorus Leach, 1816

Chydorus nitidulus (Sars, 1901)

Syn: Smirnov, 1996:132, figs. 548-550; FADA 2013:16-17.

Material examined: 2 adult females, catalog number: UARC122M.

Remarks: This species was the least abundant within the family Chydoridae and was found within macrophytes in September. Neotropical species described from Brazil (Sars, 1901).

Chydorus eurynotus (Sars, 1901)

Syn: FADA 2013:16; Fuentes-Reinés et al., 2012:149, fig. 30 .

Material examined: 4 adult females, catalog number: UARC130M.

Remarks: It was scarce within macrophytes and found only in September. This species was described from Brazil (Sars, 1901), but found worldwide in tropical and subtropical regions (Smirnov, 1971, 1996). This species group needs to be revised worldwide. 


\section{Chydorus pubescens (Sars, 1901)}

Material examined: 2 adult females, catalog number: UARC132M.

Remarks: It was scarce within macrophytes and found only in July. Valid species described form Brazil (Sars, 1901), then similar populations were found in other tropical regions. According to Kotov et al. (2013), this species needs to be revised worldwide. Probably C. pubescens is exclusively Neotropical species.

Genus Dunhevedia King, 1853

Dunhevedia odontoplax Sars, 1901

Material examined: 4 adult females, catalog number: UARC123M.

Remarks: Valid Neotropical species described from Colombia (Stingelin, 1913). It was found within macrophytes in October and December.

Genus Anthalona Van Damme, Sinev et Dumont, 2011

Anthalona verrucosa (Sars, 1901)

(Fig. 1A-F)

Syn: Van Damme et al 2011:41, figs. 20-23.

Material examined: 25 adult females, catalog number: UARC121M.

Anthalona verrucosa is characterized by an ovoid body and an especially small size, 0.25 $0.28 \mathrm{~mm}$ (Fig. 1A). Head shield with a well developed, but obtuse rostrum (Fig. 1B), two head pores (Fig. 1C), quadrangular labrum with a small denticle in anterior part (Fig. 1D); short and wide postabdomen with welldeveloped lateral fascicles of setae and short marginal denticles (Fig. 1E). Antennal formula for setae 0-0-3/1-3-3; The IDL of limb I with two setae bearing well-developed denticles, and the ODL with a single large seta, IDL with two hooked setae (Fig. 1F).

Remarks: It was one of the most common species associated to macrophytes, collected from June-December. Anthalona verrucosa was described from São Paulo, Brazil (Sars, 1901) as Alona, and have been reported in South
America, Africa and Eurasia (Smirnov, 1971; Alonso, 1996). However the true verrucosa is likely limited to Neotropics (Van Damme et al., 2011). This is the first documented record with illustrations confirming its presence in Colombia. Earlier it was simply reported for Bolivar department (Álvarez, 2010).

Genus Alona Baird, 1843

Alona glabra Sars, 1901

(Fig. 2A-F)

Syn: Kotov et al., 2010:33.

Material examined: 30 adult females and 20 adult males, catalog number: UARC117M.

The body of $A$. glabra is ovoid, size ranging from $0.38-0.42 \mathrm{~mm}$ (Fig. 2A); the taxon is different from closest Alona cambouei in three interconnected head pores (Fig. 2B) and from Alona pulchella in small $\mathrm{PP} / \mathrm{IP}$ ratio. In this case, the postabdomen is short, with small distal denticles decreasing in size proximally (Fig. 2D).

Male. Habitus similar to female (not illustrated), body range length $0.28-0.29 \mathrm{~mm}$; postabdomen short, round-quadrangular, postabdominal claw shorter than in female and possessing a basal spine a little longer than in female, about 0.45 the length claw (Fig. 2E). Trunk limb 1 with a U-shaped copulatory hook, IDL with two plumose and a single smooth male setae (Fig. 2F).

Variability: A single female had only two head pores connected, but with an obscure connection between pores 2 and 3, instead of three pores with a well-developed connection (Fig. 2C).

Remarks: It was the most common species associated with macrophyte roots, collected from April, May, June, October and November. In Colombia, it has been reported from Ciénaga Grande de Santa Marta and Andean region (Stingelin, 1913; Fuentes-Reinés et al., 2012). The male has only been described by Sinev (2001). In this research, the male was found in great proportions during the rainy season (October and November). 


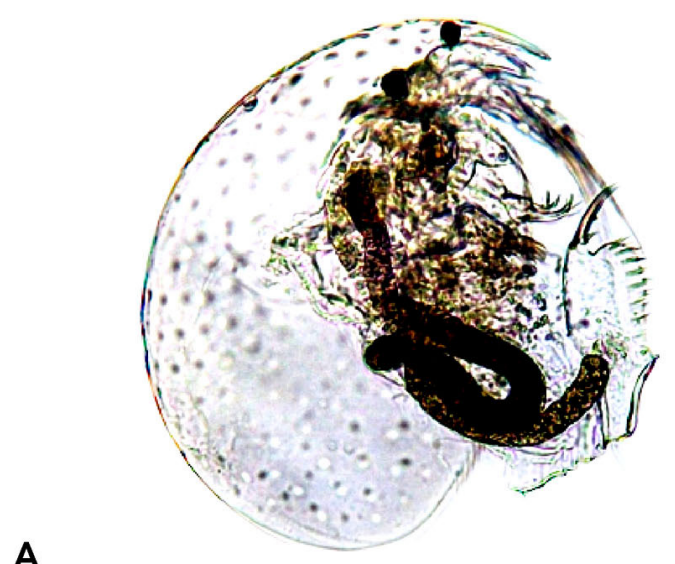

A
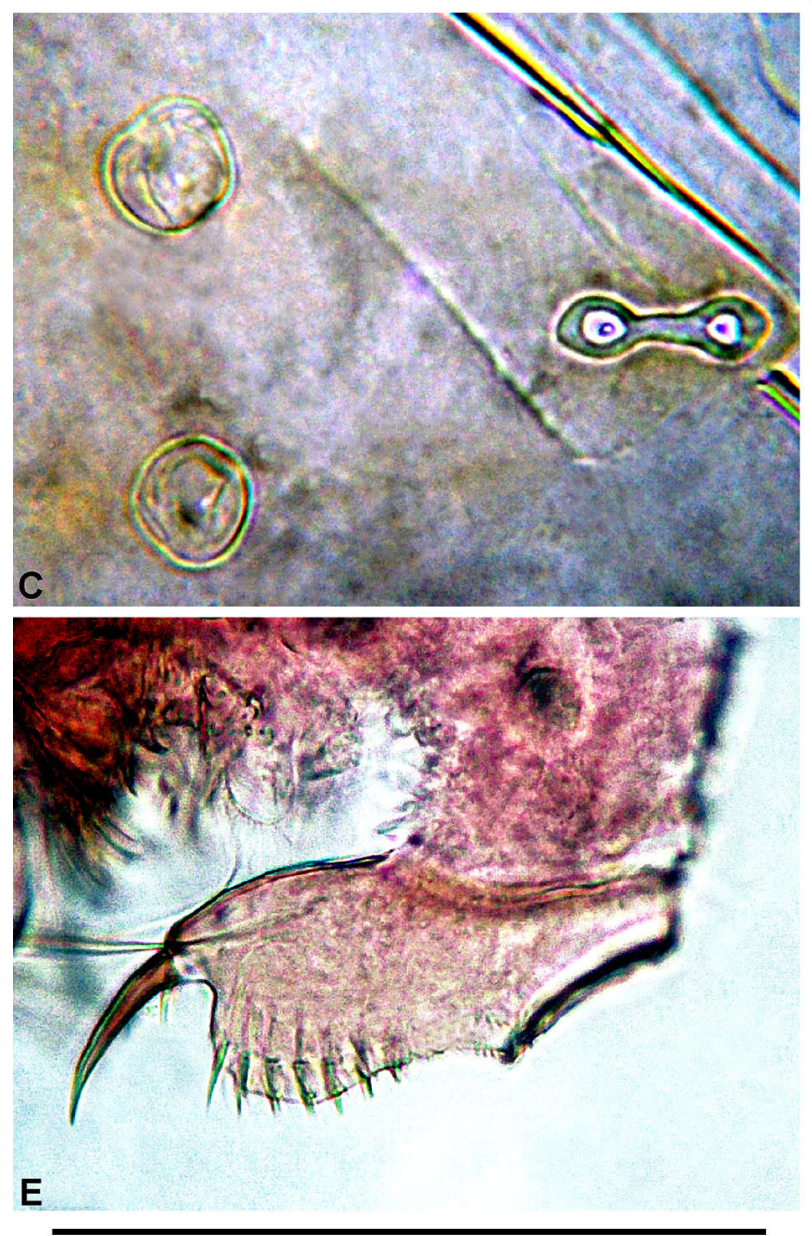
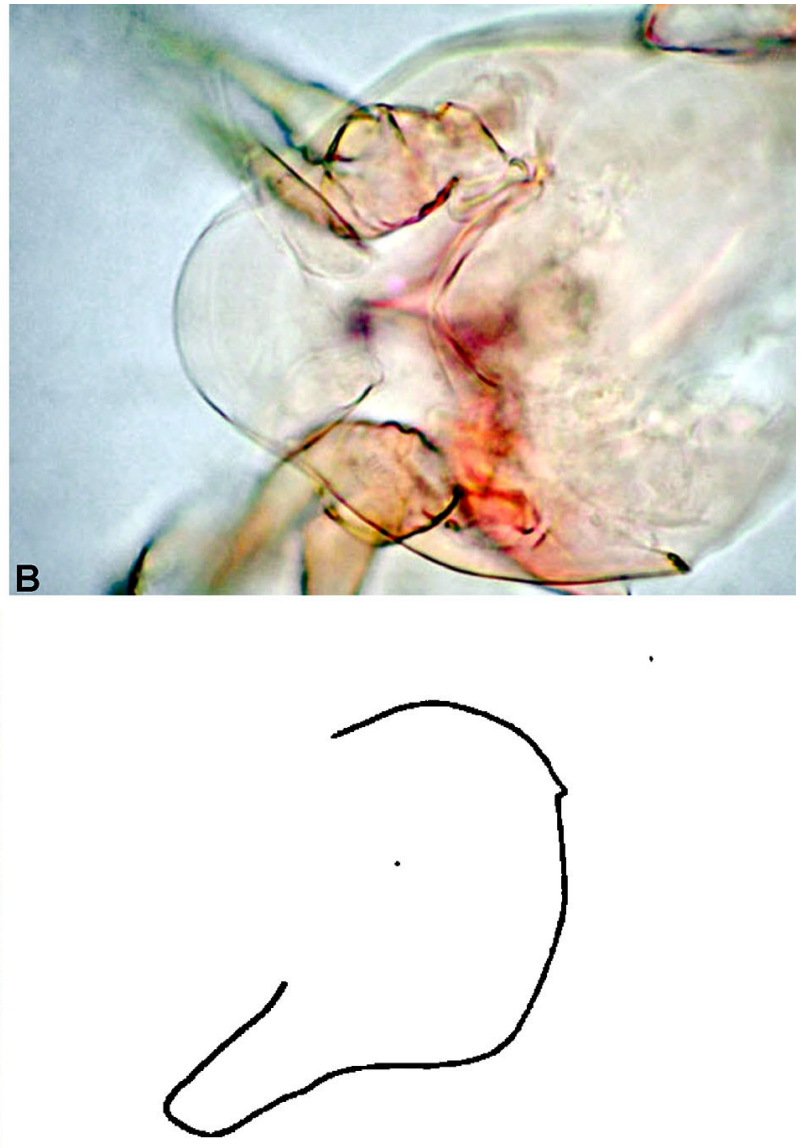

D

$\mathbf{F}$

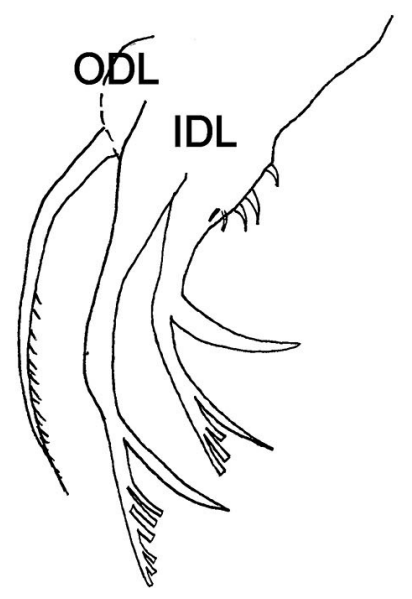

Figure 1. Anthalona verrucosa. Female. A. Habitus; B. Head shield; C. Head pores; D. Labrum. E. Postabdomen; F. IDL of limb I. Scale bars $=50 \mu \mathrm{m}$

Genus Nicsmirnovius Chiambeng et Dumont, 1999 Nicsmirnovius fitzpatricki (Chien, 1970)

(Fig. 3A-E)

Syn: Van Damme et al., 2003:42.

Material examined: 20 adult female from Laguna Navío Quebrado, northern Colombia, catalog number: UARC131M.

Body length 0.31-0.39 mm (Fig. 3A). It is characterized by three head pores with narrow connection and two lateral pores with Cosmarium-shaped structure located in the posterior part of the main head pores (Fig. 3B), a relatively large labral keel and a depression near apex (Fig. 3C). First antenna tubular, reducing in thickness at the distal part, with a long setule on it (Fig. 3D), IDL and ODL of limb I with 3 and 1 setae respectively (Fig. 


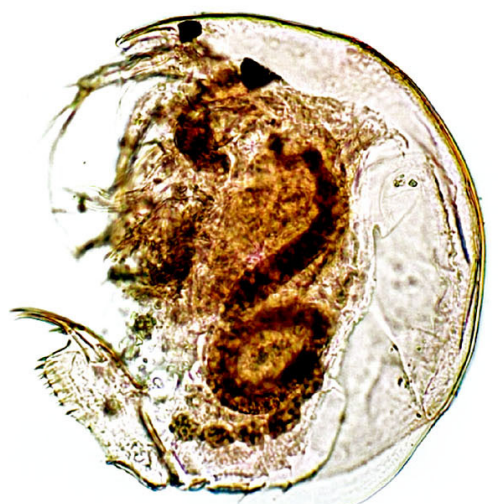

A

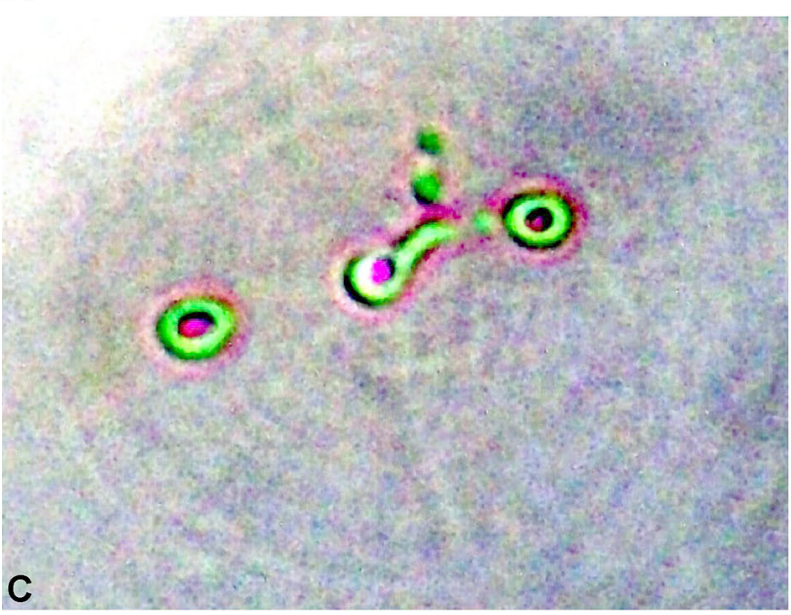

B
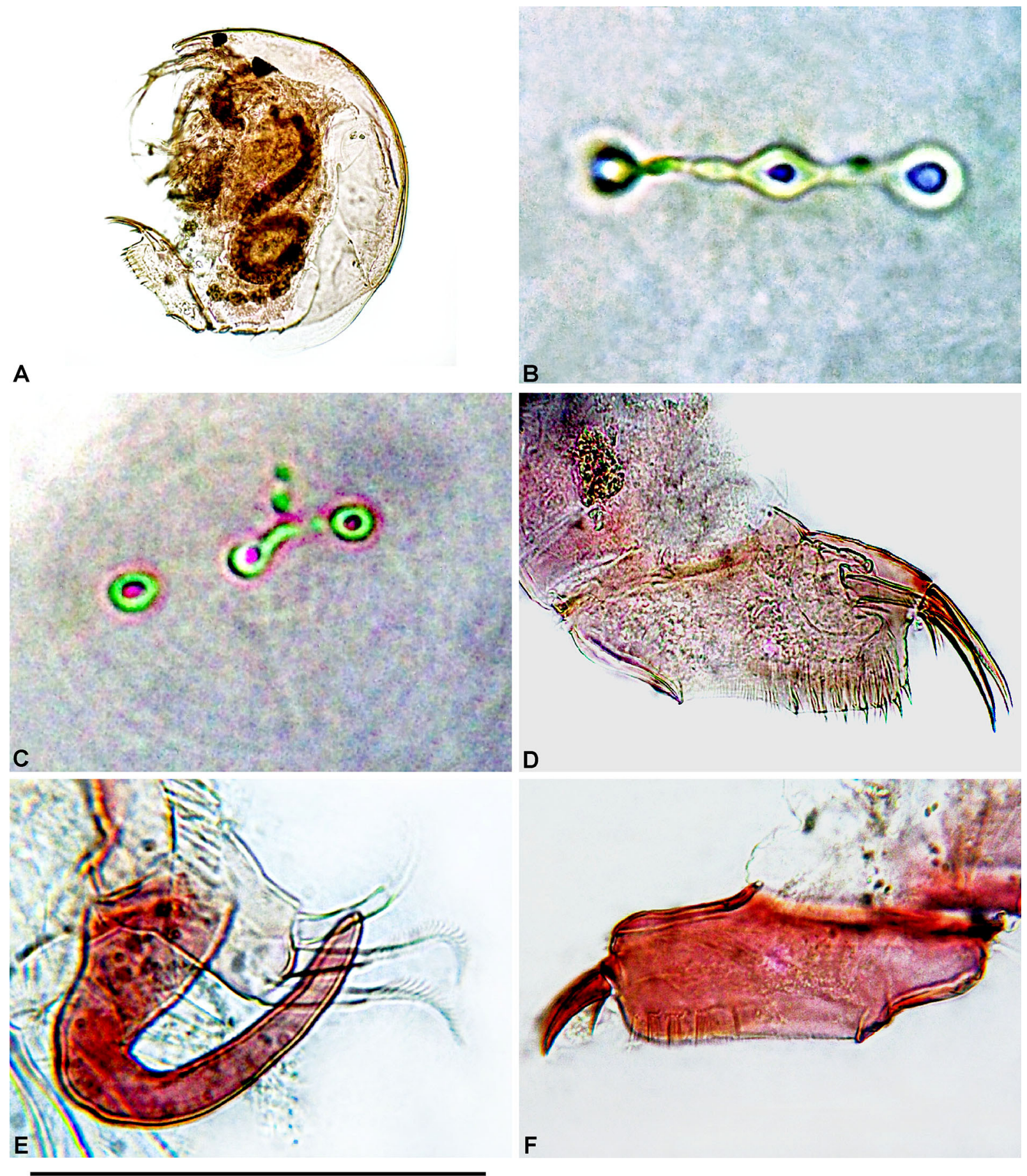

D

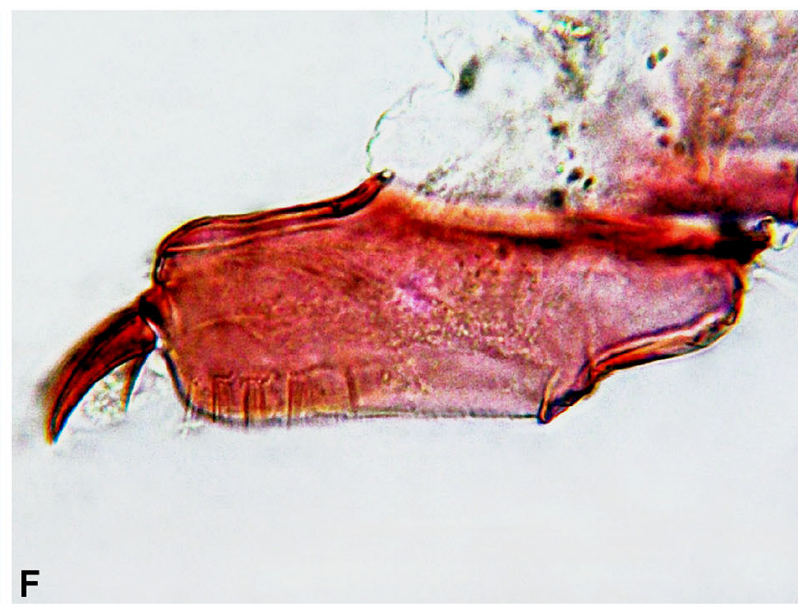

Figure 2. Alona glabra. A. Habitus. B-C. Main head pores; D. Postabdomen. Male. E. IDL of limb 1. F. Postabdomen. Scale bars = $50 \mu \mathrm{m}$.

3E), valve without reticulations, short setae on posterior-ventral valve portion (Fig. 3F), postabdomen quadrangular, with eight-nine denticles at the distal part, and lateral fascicles, its length is 2.3 times the width (Fig. 4A-D), postabdomial claw very long, its length $42 \%$ of postabdomen length, a basal spine beginning 7 $\mu \mathrm{m}$ from the base of postabdominal claw, base of claw with a pecten of six fine setules (Fig. 4E).

Variability: Two female were observed to posses the basis of postabdominal claw very reduced (Fig. 4B).

Remarks: It was found within macrophyte during rainy season (October and November). Nicsmirnovius fitzpatricki was described as Alonella fitzpatricki from the Pearl River U.S.A by Chien (1970). For years later it was reassigned to Alona eximia by Frey (1974) and 
A

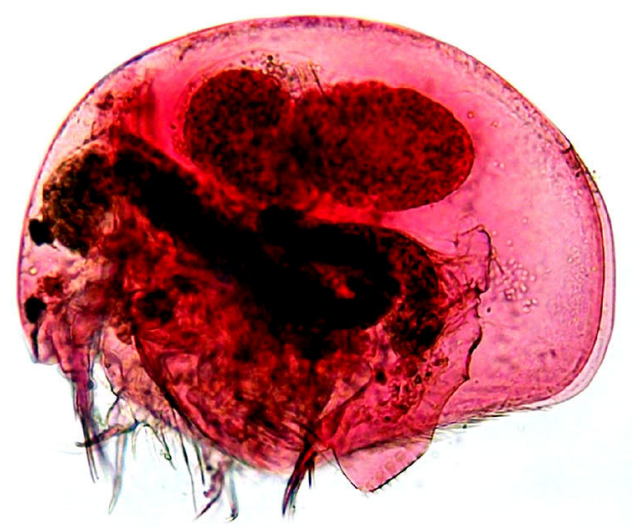

C
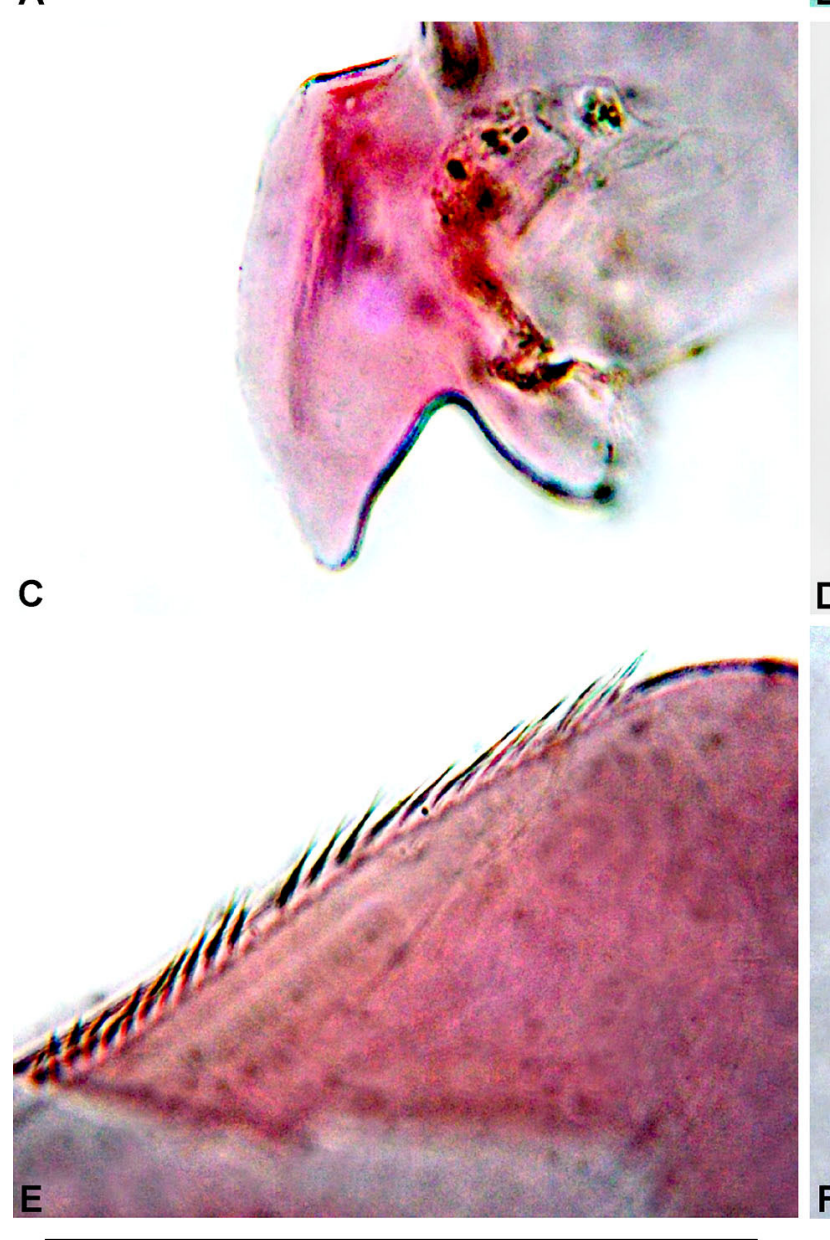
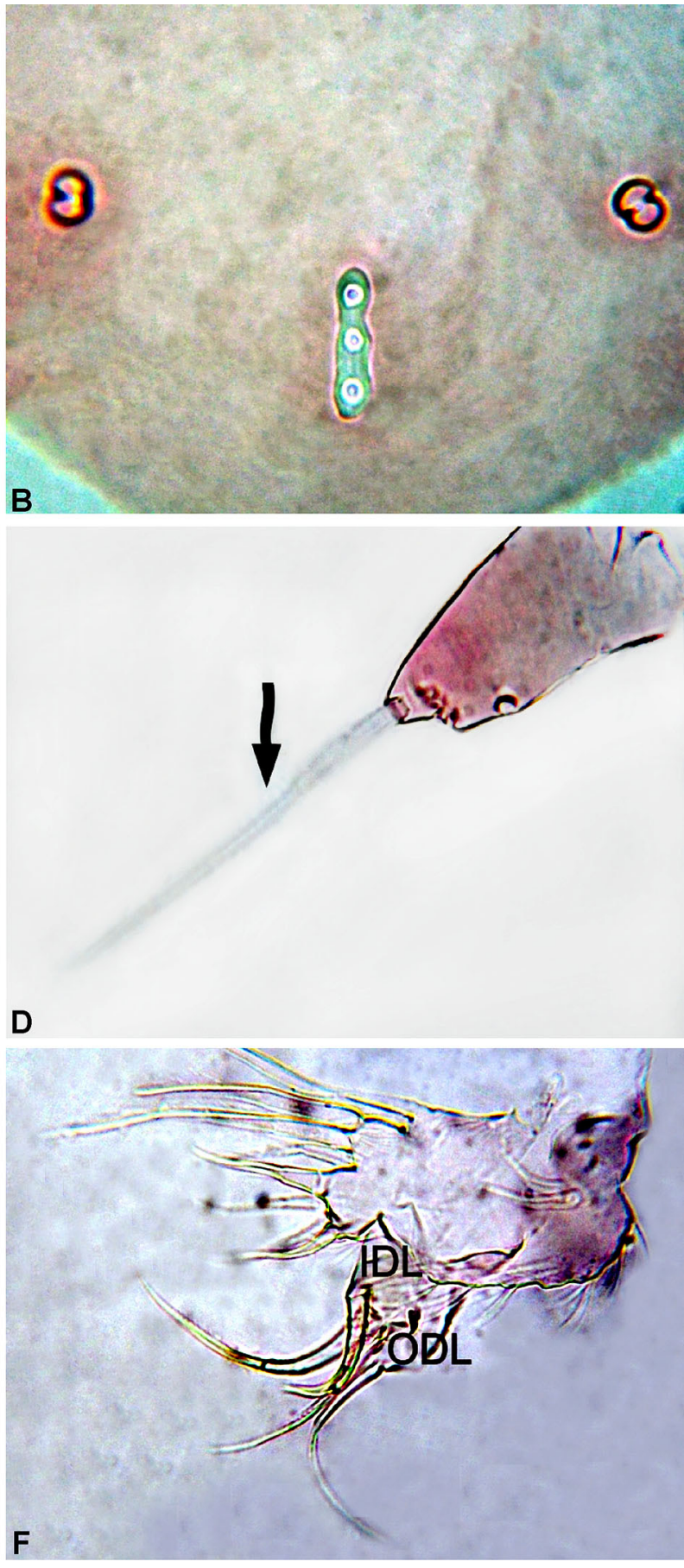

Figure 3. Nicsmirnovius fitzpatricki. Female. A. Habitus. B. Head pores. C. Labrum. D. First antenna (the Arrow points at the long setule). E. Valve setae near posteroventral corner. F. IDL and ODL of limb I. Scale bars $=50 \mu \mathrm{m}$.

finally placed in the genus Nicsmirnovius (Van Damme et al., 2003). Nicsmirnovius fitzpatricki has been reported from Puerto Rico, México (Van de Velde et al., 1978), Argentina (Paggi, 1979), Venezuela (Zoppi de Roa and López, 2008), Brasil (Vila dos Santos et al., 2011) and Colombia (Fuentes-Reinés and Zoppi de
Roa, 2013). Examined specimens beared the diagnostic features of $N$. fitzpatricki described by Van Damme et al. (2003) and FuentesReinés and Zoppi de Roa (2013). This is the second record to Colombia, with one previously reported from Magdalena department (FuentesReinés and Zoppi de Roa, 2013). 

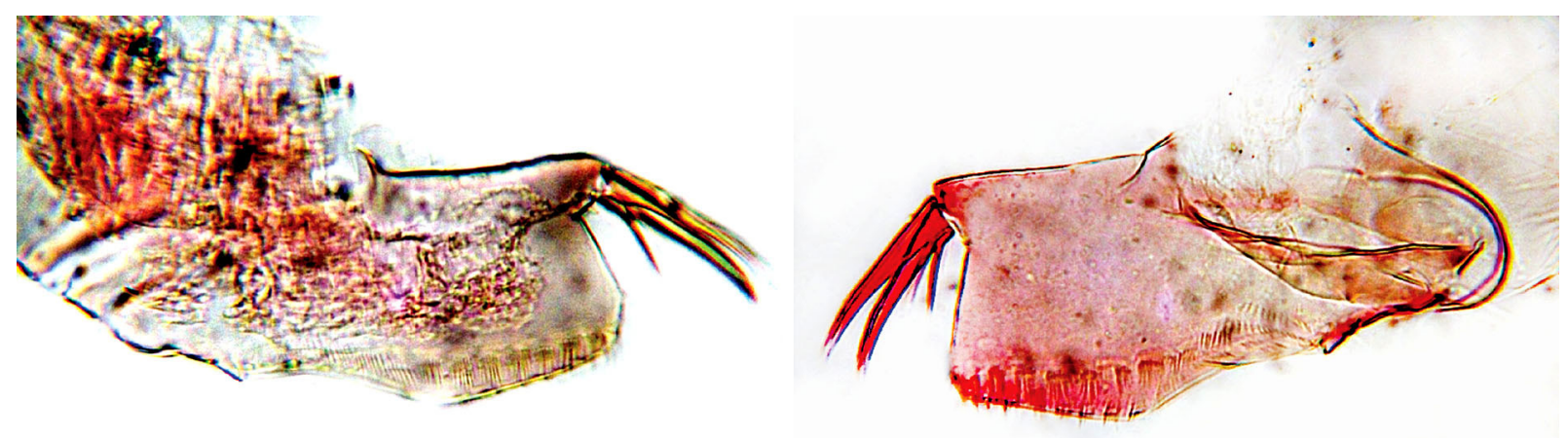

A

B
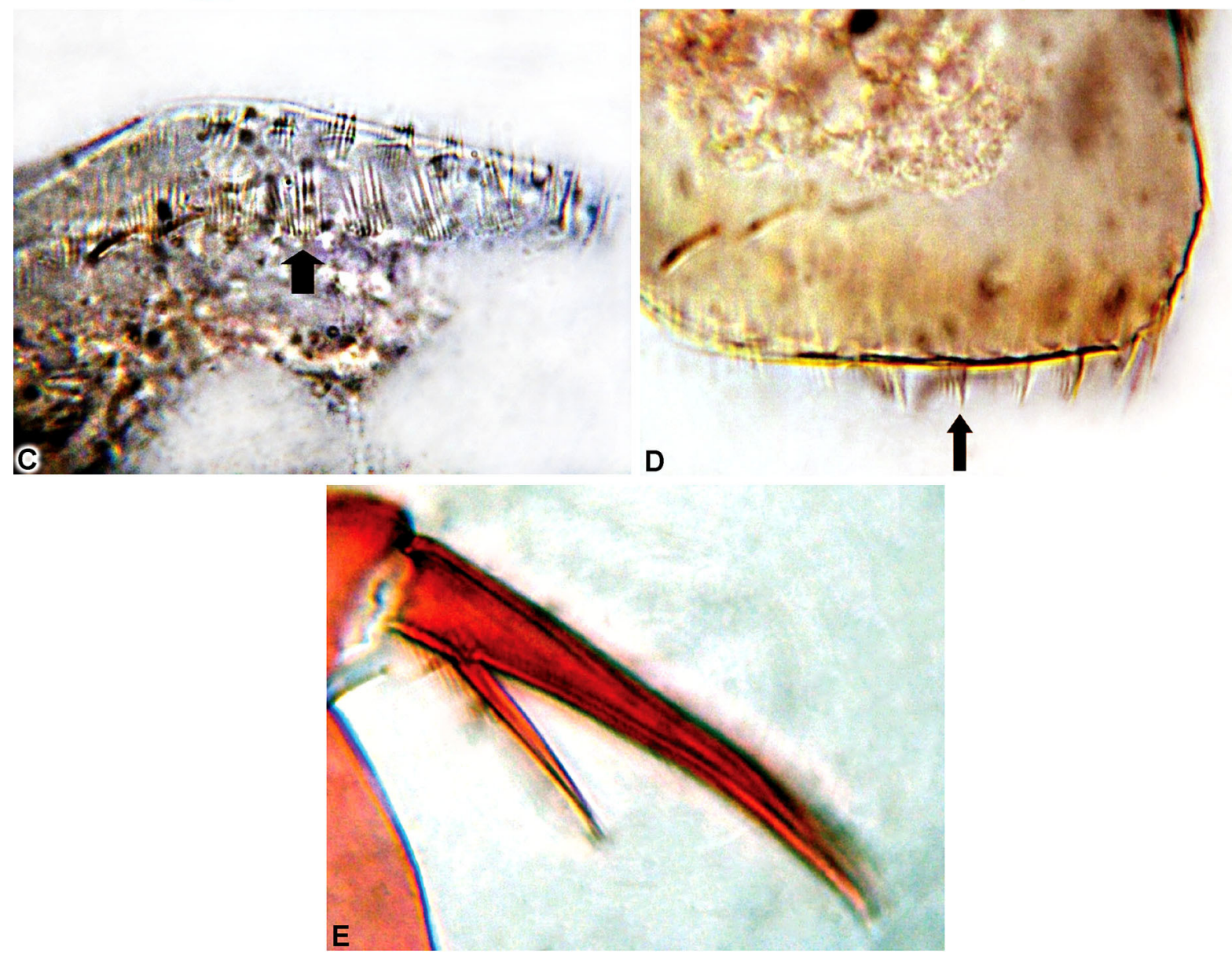

Figure 4. Nicsmirnovius fitzpatricki. A-B. Postabdomen (The arrow points at the basis of postabdominal claw). C. Lateral fascicles of postabdomen. D. Denticles at the distal part of postabdomen. E. Postabdominal claw. Scale bars $=50 \mu \mathrm{m}$.

\section{Discussion}

This study led to the finding of 17 cladoceran taxa in only a small portion of Laguna Navío Quebrado. Three most common cladocerans of the lagoon (Alona glabra, Nicsmirnovius incredibilis, Anthalona verrucosa) are littoral animals. The occurrence of these species along with Macrothrix elegans, Alona glabra, Karualona muelleri, Oxyurella ciliata, Leberis davidi, Nicsmirnovius fitzpatricki, Anthalona verrucosa, Notoalona sculpta, and Chydorus nitidulus, indicate a very typical Neotropical species assemblage. Fuentes-Reinés et al. (2012) reported the similar situation in Ciénaga 
Grande de Santa Marta. From 92 species of cladocerans reported from Colombia (FuentesReinés et al., 2013), 18.47\% are found in the Guajira department to date, but I believe this number will be significantly increased. Several taxa that could be common in the north region of Colombia are still lacking.

It remains highly probable that species such as Moina micrura, Moina minuta, Sarsilatona serricauda and Ephemeroporus hybridus could be found in the Guajira department, because they occur in other close localities (Magdalena and Córdoba department, Maracaibo state) (CarruyoNoguera et al., 2008; Fuentes-Reinés et al., 2012, 2013). The absence of these taxa in my study could be partly explained by the scarcity of the macrophytes in the studied water body. The high salinity (28 PSU) in the limnetic region could limit the presence of some cladoceran species in this zone. The majority of freshwater cladocerans are phytophylous, and just macrophytes seem to support a greater variety of microhabitats, inhabited by a large number of species (Elmoor-Loureiro, 2007).

The species richness in Laguna Navío Quebrado (17) is low as compared with the Ciénaga Grande de Santa Marta (45) and Ciénaga de Ayapel (20 species and 9 morphotypes) (Villabona-Gonzáles et al., 2011; Fuentes-Reinés et al., 2012). The absence of macrophytes in Navío Quebrado might explain its relatively low species diversity. Among the species identified, Alona glabra, Leberis davidi, and Anthalona verrucosa were recorded almost throughout all the sampling period. In contrast, Chydorus nitidulus, $C$. eurynotus, C. pubescens, Macrothrix elegans, $M$. spinosa, Euryalona orientalis, Notoalona sculpta and Oxyurella ciliata, were rare in the lagoon.

Anthalona verrucosa, A. glabra and $N$. fitzpatricki could be easily confused with other American species. The former is similar to $A$. brandorffi in the shape of antenna I; two main head pores with narrow connections, both species have tuberculated valves. Nevertheless $A$. verrucosa differs from $A$. brandorffi in the rostrum shape (its posterior margin narrow and elongated in $A$. verrucosa while in $A$. brandorff the posterior margin is broadly rounded). The most obvious differences between these two species concern: (1) the morphology of IDL of limb I (two setae are supplied with long denticles in $A$. verrucosa, while in $A$. brandorffi they are shorter); (2) labrum (with a small denticle in $A$. verrucosa and without denticle in $A$. brandorffi); and (3) distal denticles of postabdomen (shorter in $A$. brandorffi than in A. verrucosa).

Alona glabra could be confused with $A$. cambouei and $A$. pulchella, but only A. glabra is found in South America (Sinev, 2001). In the Neotropical region $N$. fitzpatricki Chien Shingming, 1970 can be confused with Nicsmirnovius incredibilis (Smirnov, 1984), but they can be separated by: (1) labral keel (elongated in $N$. fitzpatricki and rounded in N. incredibilis); (2) IDL seta of limb I (as long as IDL seta in $N$. fitzpatricki while in $N$. incredibilis is longer); (3) postabdomen (with single distal angle in $N$. fitzpatricki while in $N$. incredibilis with a doubled angle); (4) postanal portion of the postabdomen (with clusters of long setules in $N$. incredibilis vs. robust denticles in $N$. fitzpatricki); and (5) postadominal claw (with basal spine very long in $N$. fitzpatricki while short in $N$. incredibilisis). In Nicsmirnovius fitzpatricki from Colombia the postabdomen is compact as in the Argentinian specimens. According to Van Damme et al. (2003), American populations of the genus still need to be revised.

The studies of Colombian cladocerans need to be continued. Only accurate determinations according to recent level of taxonomic analysis could lead to adequate understanding of their biodiversity. Before a strong improvement of our knowledge on faunistic composition of the Neotropical cladocerans, subsequent analysis of their biogeography, ecological preferences etc. seem to be pre-mature.

ACKNOWLEDGEMENTS - I want to thank to Dr. Romi Burks for reviewing the English version and Dr. Alexey Kotov for his comments in the text. 


\section{REFERENCES}

Alonso, M. 1996. Crustacea, Branchiopoda. p. 1-486. In: M.A. Ramos (ed), Fauna Ibérica, Vol. 7. Museo Nacional de Ciencias Naturales, Madrid, CSIC.

Álvarez, J. 2010. Caracterización de las ciénagas de Arcial, Porro y Cintura (río San Jorge) y de Bañó Charco Pescao y Pantano Bonito (Río Sinú), departamento de Córdoba. p. 509-558. In: J.O. Rangel (ed), Colombia, diversidad biótica IX, Ciénaga de Córdoba: Biodiversidad, ecología y manejo ambiental. Bogotá, Universidad Nacional de Colombia.

Aranguren-Riaño, N.; Monroy, D. and Gaviria, S. 2010. Eurycercus (Bullatifrons) norandinus (Crustacea: Branchiopoda: Eurycercidae), a new species of Cladocera in the neotropical region. Zootaxa, 2550: 58-68.

Barón-Rodríguez, M.; Gavilán, R. and Ramírez J.J. 2006. Variabilidad espacial y temporal en la comunidad de cladóceros de la Ciénaga de Paredes (Santander, Colombia) a lo largo de un ciclo anual. Limnética, 25(3): 624-635.

Barón-Rodríguez, M. and Díaz, G. 2007. New record of Ephemeroporus tridentatus Bergamin, 1939 (Crustacea; Anomopoda; Chydoridae) from Colombia. Brazilian Journal of Biology, 67(2): 381382.

Bekker E.I.; Kotov, A.A. and Elmoor-Loureiro, L.A.M. 2010. The genus Eurycercus Baird, 1843 (Cladocera: Eurycercidae) in the Neotropics. Journal of Natural History, 44: 2481-2508.

Bergamin, F. 1939. Os Cladocera. (Descrição sistemática das espécies encontradas no município de São Paulo). Revista da Industria Animal, N.S., 2: 80-86.

Brehm, V. 1956. Cladocera aus Venezuela. Ergebn. der Deutschem limnol. Venezuela-Expedition 1952, 1: 217-232.

Camargo, L.F. 1994: Estudio cualitativo y semicuantitativo del zooplankton superficial en el Embalse El Guájaro (Atlántico), Colombia. Trianea (Act. Cien.Tecn. INDERENA), 5: 235 - 253.

Chien, S.M. 1970. Alonella fitzpatricki sp.n. and A. leei sp. n.: new Cladocera from Mississippi. Transactions of the American Microscopical Society, 89: 532-538.

Dumont, H.J.; Silva-Briano, M. and Subash-Babu, K.K. 2002. A re-evaluation of the Macrothrix roseatriserialis group, with the description of two new species (Crustacea Anomopoda: Macrothricidae). Hydrobiologia, 467: 1-44.

Elías-Gutiérrez, M.; Suárez, E.; Gutiérrez, M.; Silva, M.; Granados, J. and Garfia, T. 2008. Cladócera y Copépoda de las aguas continentales de México. UNAM, México D.F. 323 p.

Elmoor-Loureiro, L.A.M. 1997. Manual de identificação de cladóceros límnicos do Brasil. Universidade Católica de Brasília, Brasilia, Universa. 156 p.

Elmoor-Loureiro, L.M.A. 2007. Phytophilous cladocerans (Crustacea, Anomopoda and Ctenopoda) from Paranã River Valley, Goiás, Brazil. Revista Brasileira de Zoologia, 24, 344-352.

Forró, I.; Korovchinsky, M.M.; Kotov, A.A. and Petrusek, A. 2008. Global diversity of cladocerans (Cladocera; Crustacea) in freshwater. Hydrobiologia, 595: 177-184

Frey, D.G. 1974. Reassignment of Alonella fitzpatricki and A. leei Chien, 1970 (Cladocera, Chydoridae). Transactions of the American Microscopical Society, 93: 162-170.
Frey, D.G. 1987. The taxonomy and biogeography of the Cladocera. Hydrobiologia, 145: 5-17.

Fuentes-Reinés, J.M. and Elmoor-Loureiro, L.M.A. 2011. Occurrence of Guernella raphaelis Richard, 1892 (Crustacea: Cladocera: Macrothricidae) in Ciénaga Grande de Santa Marta, Colombia. CheckList, 7(6): 817-819.

Fuentes-Reinés, J.M.; Zoppi de Roa, E.; Morón, E.; Gámez, D. and López, C. 2012. Conocimiento de la Fauna de Cladocera (Crustacea: Branchiopoda) de la Ciénaga Grande de Santa Marta, Colombia. Boletín de Investigaciones Marinas y Costera, 41(1): 121-164.

Fuentes-Reinés, J.M and Zoppi de Roa, E. 2013. New additions to the cladoceran fauna of Ciénaga Grande de Santa Marta and Colombia. CheckList, 9(1): 9-24.

Gaviria, S. 2001. Estado actual del conocimiento de la biodiversidad y biogeografía de los cladóceros y copépodos de las aguas epicontinentales de Colombia. 71-73. In: P. Muñoz (ed), Memorias Primer Congreso Colombiano de Zoología Año 2000. Instituto de Ciencias Naturales, Bogotá. Universidad Nacional de Colombia.

Goulden, C.E. 1968. The systematics and evolution of the Moinidae. Transactions of the American Philosophical Society, 58: 1-101.

Herrera-Martínez, W. and Guillot, G. 1999. Composición taxonómica del zooplankton del Embalse de Betania, Departamento del Huila. Acta Biológica Colombiana, 4(1): 5-21.

Herrick, C.L. 1882. Notes on some Minnesota Cladocera. Geological and Natural History Survey of Minnesota. 10th Annual Report, 235-252.

King, R.L. 1853. On Australian Entomostraca - in continuation. Papers and Proceedings of Royal Society of Tasmania, 2: 253-263.

Kotov, A.A. 2003. Notes on Aloninae Dybowski \& Grochowski, 1894 emend. Frey, 1967 (Cladocera: Anomopoda: Chydoridae): 1. Translocation of Alona incredibilis Smirnov, 1984 to the genus Nicsmirnovius Chiambeng \& Dumont, 1999. Arthropoda Selecta. 12(3): 167-170.

Kotov, A.A. and Dumont, H.J. 2000. Analysis of the Ilyocryptus spinifer s. lat. species group (Anomopoda, Branchiopoda), with description of a new species. Hydrobiologia, 428: 85-113.

Kotov, A.A.; Garfias-Espejo, T. and Elías-Gutiérrez, M. 2004. Separation of two Neotropical species: Macrothrix superaculeata (Smirnov, 1982) versus $M$. elegans Sars, 1901 (Macrothricidae, Anomopoda, Cladocera). Hydrobiologia, 517: 61-88.

Kotov, A.A. and Ferrari, F.D. 2010. The taxonomic research of Jules Richard on Cladocera (Crustacea:Branchiopoda) and his collection at the National Museum of Natural History, U.S.A. Zootaza, 2551: 37-64.

Kotov, A.A.; Sinev, A. and Berrios, L. 2010. The Cladocera (Crustacea: Branchiopoda) of six high altitude water bodies in the North Chilean Andes, with discussion of Andean endemism. Zootaxa, 2430: 1-66.

Kotov, A.A.; Van Damme, K.; Bekker, E.; Siboualipha, S.; Silva-Briano, M.; Ortiz, A.; De La Rosa, R. and Sanoamuang, L. 2013. Cladocera (Crustacea: Branchiopoda) of Vientiane province and municipality, Laos. Journal of Limnology, 72(s2): 81108. 
Paggi, J. 1979. Aportes al conocimiento de la fauna Argentina de cladóceros. II. Sobre Alona eximia, Kiser, 1948. Neotropica, 25(74): 177-186.

Paggi, J. 2004. Importancia de la fauna de "Cladóceros" (Crustácea, Branchiopoda) del Litoral Fluvial Argentino. INSUGEO. Miscelánea, 12: 239-246.

Pearse, A.S. 1915. An account of the Crustacea collected by the Walker Expedition to Santa MartaColombia. Proceedings United States National Museum, 49(2123): 530-556.

Rajapaksa, R. and Fernando, C.H. 1987. Redescription and assignment of Alona globulosa Daday, 1898 to a new genus Notoalona and a description of Notoalona freyi sp. nov. Hydrobiologia, 144(2): 131-153.

Richard, J. 1895. Sur quelques Entomostracés d'eau douce d'Haïti. Mémoires de la Société zoologique de France, 8:189-199

Richard, J. 1897. Entomostracés de l'Amérique du Sud, recueillis par MM. U. Deiters, H. von Ihering, G.W. Müller et C.O. Poppe. Mémoires de la Société zoologique de France, 10: 263-301.

Sars, G.O. 1901. Contributions to the knowledge of the freshwater Entromostraca of South America, as shown by artificial hatching from the dried material. Archiv für Mathematik og Naturvidenskab, Christiana, 23: 1-102.

Sharma P. and Kotov, A.A. 2013. Molecular approach to identify sibling species of the Ceriodaphnia cornuta complex (Cladocera: Daphniidae) from Australia with notes on the continental endemism of this group. Zootaxa, 3702(1): 79-89.

Sinev, A.Y. 2001. Redescription of Alona glabra Sars, 1901, a South American species of the pulchella group (Branchiopoda: Anomopoda: Chydoridae). Arthropoda Selecta, 10(4): 273-280.

Sinev, A. and Hollwedell, W. 2002. Alona brandorffi sp. n. (Crustacea: Anomopoda: Chydoridae) - a new species from Brazil, related to $A$. verrucosa Sars, 1901. Hydrobiologia, 472: 131-140.

Sinev, A.Y.; Van Damme, K. and Kotov, A.A. 2005. Redescription of tropical-temperate cladocerans Alona diaphana King, 1853 and Alona davidi Richard, 1895 and translocation to Leberis Smirnov, 1989 (Branchiopoda: Anomopoda: Chydoridae). Arthropoda Selecta, 14(3): 183-205.

Sinev, A.Y. and Hollwedel, W. 2005. Translocation of Alona muelleri Richard, 1897 into the genus Karualona Dumont and Silva-Briano, 2000 (Branchiopoda: Anomopoda: Chydoridae). Arthropoda Selecta, 14(2): 93-101.

Smirnov, N.N. 1971 Chydoridae fauny mira. Fauna USSR. Rakoobraznie, 1, Leningrad, 531 pp. (English translation: Chydoridae of the world. Israel Program for Scientific Translations, Jerusalem, 1974).

Smirnov, N.N. 1974. Fauna of the USSR. Crustacea, Chydoridae. Jerusalem: Keter Publishing House. $644 \mathrm{p}$.

Smirnov, N.N. 1976. Macrothricidae and Moinidae of the World fauna. Fauna SSSR, novaya seriya. Rakoobraznye, 1(3): 1-237 (In Russian).

Smirnov, N.N. 1984. Some comments on tropical littoral Cladocera, with a description of Alona incredibilis sp. nov. Hydrobiologia 113: 155-158.

Smirnov, N.N. 1992. The Macrothricidae of the world. SPB Academic Publishing, Ámsterdam. 143 p.

Smirnov, N.N. 1996. Cladocera: the Chydorinae and Sayciinae (Chydoridae) of the World. p. 1-197. In: H.J.F. Dumont (ed), Guide to Identification of Macroinvertebrates of the Continental Waters of the World, Vol. 11. Amsterdam, Backhuys Publishers.
Sousa, F.D.R. and Elmoor-Loureiro, L.M.A. 2008. Cladóceros fitófilos (Crustacea, Branchiopoda) do Parque Nacional das Emas, estado de Goiás. Biota Neotropica, 8(1):159-166.

Stingelin, T. 1913. Cladoceren aus den Gebirgen von Kolumbien. Mem. Soc. Neuchateloise. Memoires de la Société Neuchâteloise des Sciences Naturelles, 5: 600-638.

Van Damme, K.; Chiambeng, V.; Maiphae, V and Dumont, V. 2003. New species in the rheophilous genus Nicsmirnovius Chiamberg and Dumont 1999 (Branchiopoda: Anomopoda: Chydoridae) and reassignment of Alona eximia Kiser, 1948 and Alonella fitzpatricki Chien, 1970. Hydrobiologia, 499: 25-49.

Van Damme, V.K. and Dumont, H.J. 2010. Cladocera of the Lençóis Maranhenses (NE - Brazil): faunal composition and a reappraisal of Sars' Method. Brazilian Journal of Biology, 70(3): 755-779.

Van Damme, K.; Kotov, A.A. and Dumont, H.J. 2010. A checklist of names in Alona Baird, 1843 (Crustacea: Cladocera: Chydoridae) and their current status: an analysis of the taxonomy of a lump genus. Zootaxa, 2330: 1-63.

Van Damme, K.; Sinev, A. and Dumont, H.J. 2011. Separation of Anthalona gen.n. from Alona Baird, 1843 (Branchiopoda: Cladocera: Anomopoda): morphology and evolution of scraping stenothermic alonines. Zootaxa, 2875: 1-64.

Van Damme, K. and Maiphae, S. 2013. Salinalona gen. nov., an euryhaline chydorid lineage (Crustacea: Branchiopoda: Cladocera:Anomopoda) from the Oriental region. Journal of Limnology, 72(Suppl.2): 142-173.

Van de Velde, I.; Dumont, V and Grootaert, V. 1978. Report on a collection of Cladocera from Mexico and Guatemala. Archiv für Hydrobiologie, 83: 391404.

Vila dos Santos V.; Lansac-Toha, F. and Costa, C. 2011. Estrutura das assembléias de cladóceros em reservatórios nos estados de São Paulo e Paraná: gradientes espaciais E grau de trofia. Oecologia Australis, 15(3) 494-510.

Villabona-González, S.L.; Aguirre, N.J. and Estrada, A.L. 2011. Influencia de las macrófitas sobre la estructura poblacional de rotíferos y microscrustáceos en un plano de inundación tropical. Revista de Biología Tropical, 59(2):853-870.

Villalobo, M. and González, E. 2006. Estudios sobre la biología y ecología de ceriodaphnia cornuta Sars: Una Revisión. Interciencia, 31(5): 351-357.

Zaret, T. 1969. Predation-balanced polymorphism of Ceriodaphnia cornuta Sars. Limnology and oceanography, 14: 301-303.

Zoppi de Roa, E. and López, C. 2008. An updated checklist of inland Cladocera (Crustacea: Orders Ctenopoda and Anomopoda) from Venezuela. Zootaxa, 1919: 45-57. 